\title{
Knappable lithic resources of North-Western Romania: A mineralogical study
}

\author{
Otis Crandell \\ Babeș-Bolyai University, Geology Department, Cluj-Napoca, Romania. Email: otis.crandell@ubbcluj.ro
}

\begin{abstract}
:
The purpose of this study is to identify and characterise some of the raw materials in NW Romania which have been suggested as having been used for knapping tools. The materials cropping out in this area include jasper, chalcedony, and perlite. The basic characteristics of the materials, obtained by macroscopic, microscopic, and X-ray powder diffraction (XRPD) investigations provide a reference database useful in provenance studies on individual artefacts or whole assemblages. An assessment of each material is made regarding its quality as a knappable material.
\end{abstract}

Keywords: knappable material; lithic tools; jasper; perlite; chalcedony; lithotheque; Eastern Carpathians; NW Romania

\section{Introduction}

Knowledge of the potential geological sources for knappable materials in a certain area is of great importance in archaeology, in particular when studying production and trade of lithic tools in prehistory. In order to determine which artefacts were imported, it is first necessary to understand which artefacts could be of local origin, especially in the case of materials of similar appearance. In many cases though, the local raw materials are rarely described in details in the archaeological literature.

The aims of this paper are to identify and characterise materials of mineral origin outcropping out in the NW part of Romania (Figure 1), which may be suitable for knapping tools or have been suggested as sources of knapped stone artefacts. It is intended that the information and example images presented here will be of use in provenance studies of lithic assemblages from the study area. The data may be used either as references to which artefacts can be compared. The samples collected during this study are part of a larger lithotheque and will also be of use in future sourcing studies. Being able to compare artefacts with samples of potential raw materials helps to narrow down possible sources (Turq 2005).

Published by the School of History, Classics and Archaeology, University of Edinburgh ISSN: 2055-0472. URL: http://journals.ed.ac.uk/lithicstudies/

This work is licensed under a Creative Commons Attribution 2.5 UK: Scotland License. 


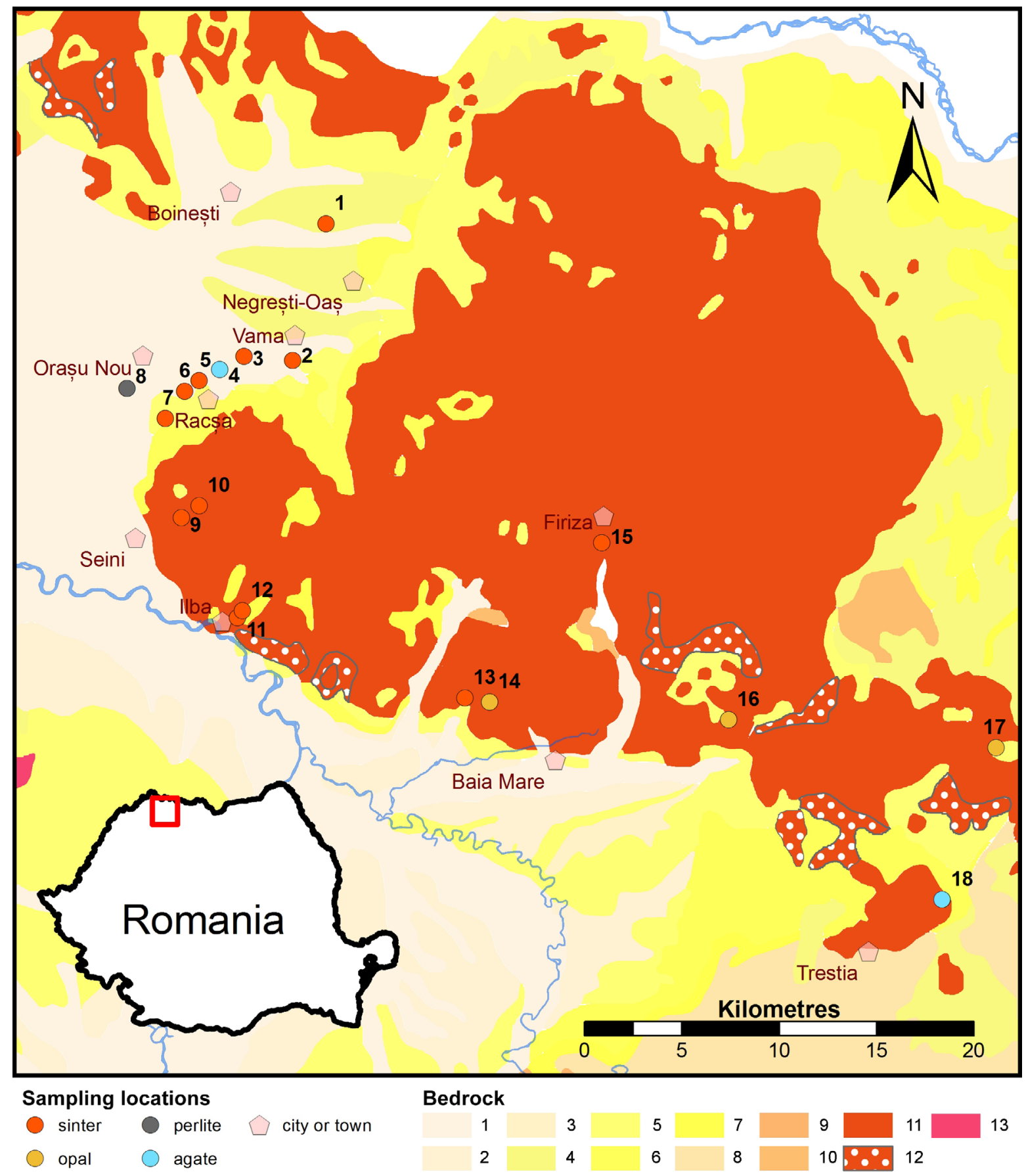

Figure 1. Simplified geological map of the Maramureș region and locations where raw materials were sampled: Sinter (jasper): 1. Alba R. (Negrești-Oaș); 2. Vama; 3. Vama - Racșa; 5. \& 6. Racșa; 7. Cremenea Hill (Racșa); 9. \& 10. Seini; 11. \& 12. Ilba; 13. Borcuţul Valley (Baia Mare); 14. Iricău Peak and Roşie Valley (Baia Mare); 15. Firiza. Opal: 14. Iricău Peak (Baia Mare); 16. Baia Sprie; 17. Cavnic. Chalcedony (agate): 4. Racșa; 18. Trestia. Perlite: 8. Orașu Nou. Silicified wood: 8. Oraşu Nou. Bedrock geology: 1 to 4. Quaternary; 5. Pliocene; 6 \& 7. Miocene; 8. Oligocene; 9 \& 10. Paleocene + Eocene; 11 \& 12. Neogene pyroclastics \& andesites; 13. Upper Precambrian. The inset in the lower left shows the location of the area (red rectangle) within Romania. Geological map based on Săndulescu et al. (1978) modified by Tudor (2009) and the author of this study.

\section{Materials}

The study region covers the NW extreme of Romania, specifically the Gutâi and Oaș Mountains (belonging to the Eastern Carpathians) and the depression in between (named the Oaș Depression). The most abundantly found materials which some researchers have suggested may have been used to knap artefacts are related to the Neogene volcanics - jasper 
(sinter and opal), chalcedony and perlite (Săndulescu et al. 1978). (See Figure 1) As well, there are various other materials, of lower quality, such as silicified wood, andesite and quartzite, which are found in the region. They will not be addressed here. The chosen materials were subjectively assessed regarding their quality for producing knapped tools. The main characteristics considered how regular (predictable) of a conchoidal fracture they produced, how fine grained they were, and their durability. Although this assessment is partially subjective, it is an important observation since it is one that prehistoric people would have also made.

Jasper can be found at numerous locations in Satu Mare and Maramureș counties, along the general boundary between the Oaș Depression and the Gutâi Mts. to the east. The presence of this material and its sources have been mentioned by numerous researchers. It has been referred to by various names, e.g., jasper, sinter, opal, and limnic quartzite. Pop et al. (2004) have mentioned it as opal (Orașu Nou occurrence). Ghiurcă and Chira (1998) described a polychrome stratified jasper and opal at Seini and describe the material as being of limnic origin. 'Jasper' occurrences near Târna Mare, Certeze, Cavnic, Băiuț, and Trestia (Figures 1 and 2), as well as in the Lăpuș, Porcului and Maria Valleys were presented by Ghiurcă and Chira (1998). Givulescu (1967: 91-92) mentions jaspers on Piciorul Porcului Hill (also referred to as 'Porcului Hill') (Figure 3) outside the town of Ilba. Iorgulescu describers microcrystalline quartz of different colours (brownish-red and whitish hues) in tuffs and diatomites on Porcului Hill (Iorgulescu 1955: 74). Rădulescu (1960) notes that in the Sarmatian deposits there are 'sands with lenses of hard siliceous rock.' Various sources of this material were identified and sampled near the towns of Boinești, Negrești-Oaș, Vama, Racşa (particularly on Cremenea Hill), Seini, Ilba, Baia Mare, Firiza, Baia Sprie, and Cavnic (see Figures 1 to 3).

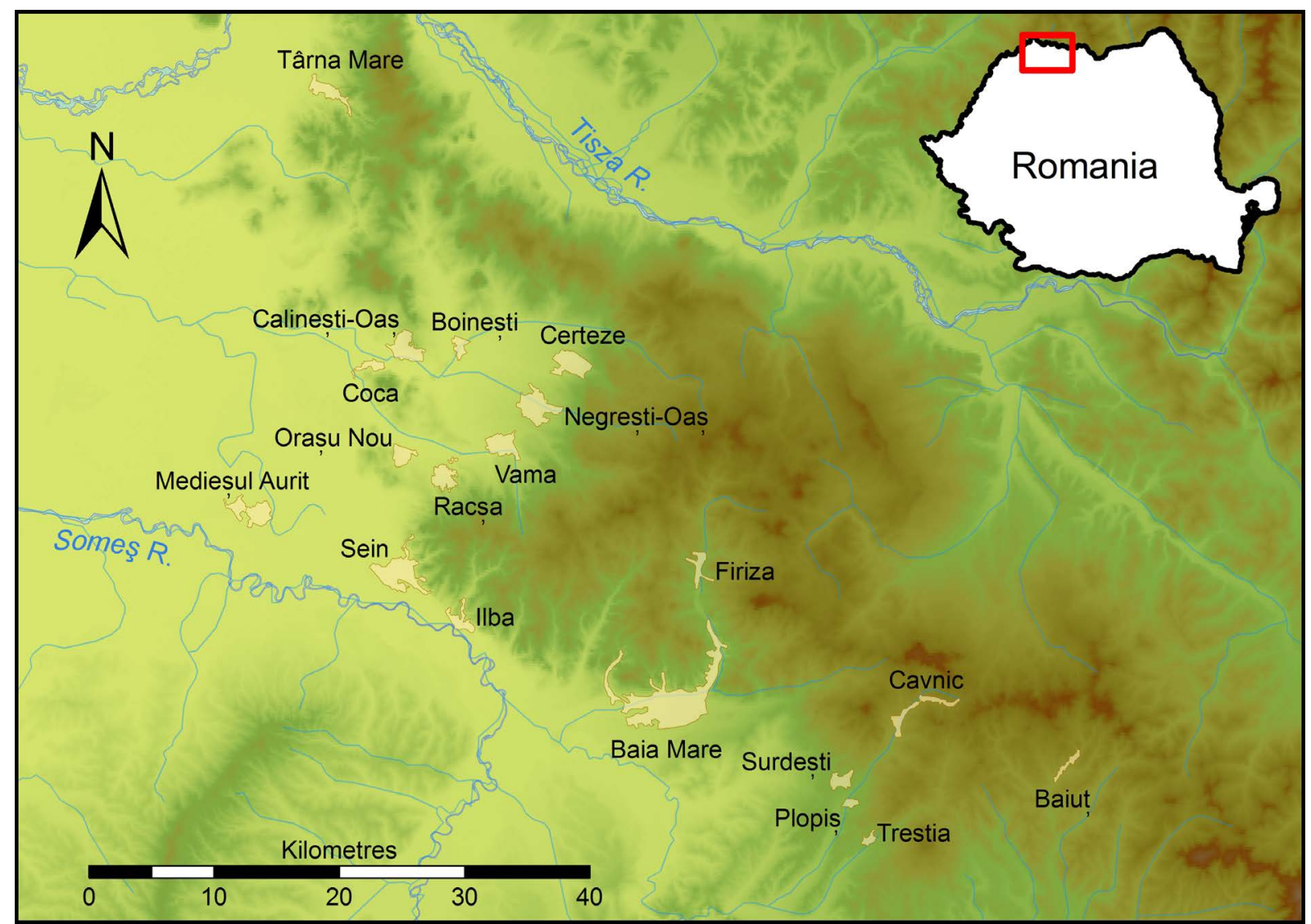

Figure 2. Relief map indicating locations mentioned in the text. The inset in the upper right shows the location of the area (red rectangle) within Romania. Relief map produced from data provided by the SRTM (2000). 


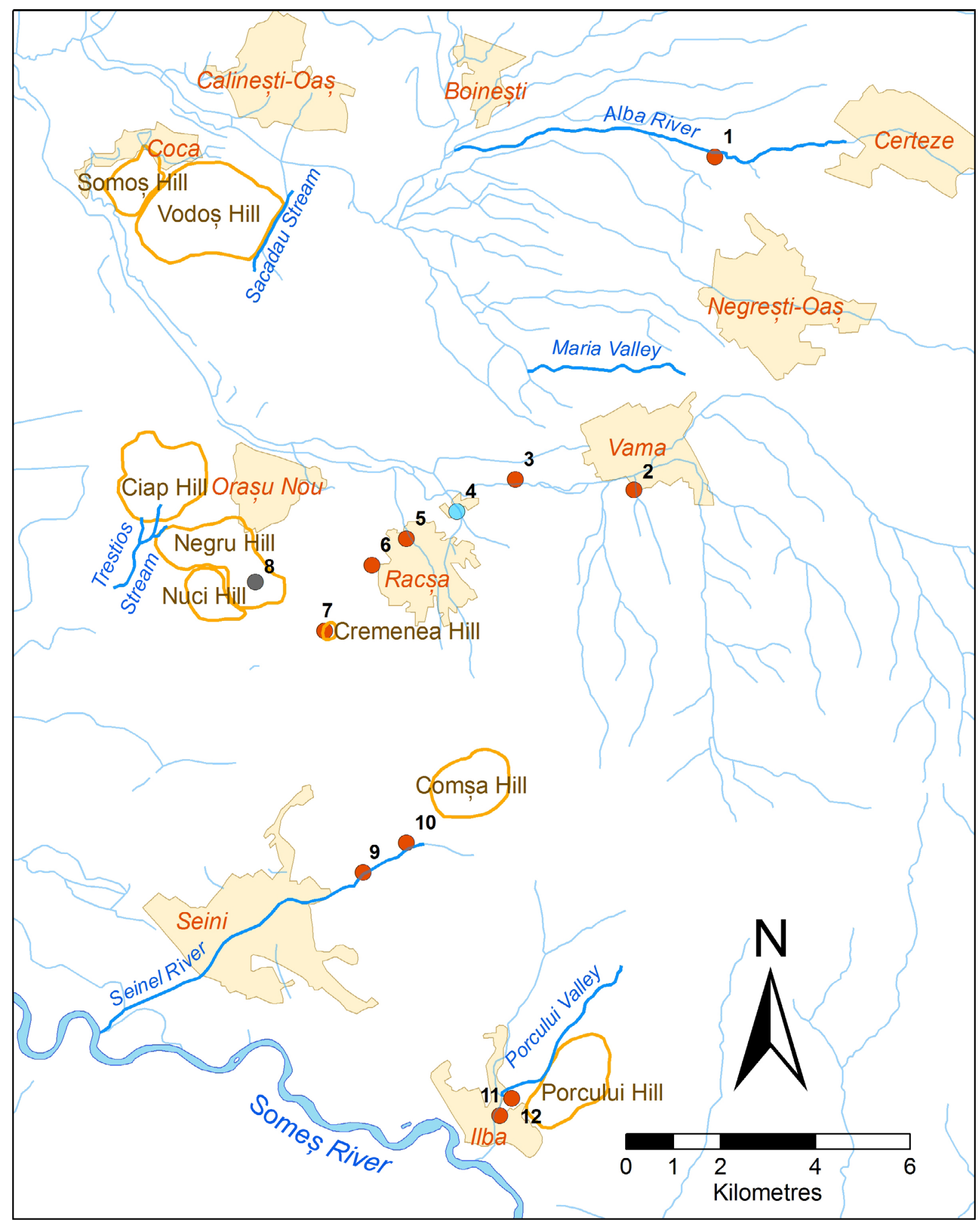

Figure 3. Specific geographic features mentioned in the text. Sampling locations: 1. Alba R. (Negrești-Oaș); 2. Vama; 3. Vama - Racșa; 4., 5. \& 6. Racșa; 7. Cremenea Hill (Racșa); 9. \& 10. Seini; 11. \& 12. Ilba.

Neogene hyaloclastic rhyolite (perlite) is found in the area near the town of Orașu Nou (within approximately $10 \mathrm{~km}$, but particularly from Orașu Nou to Coca) in Satu Mare County. Perlite has been extracted for commercial purposes at several quarries in the area. Perlite outcrops are found near the town of Coca (part of Călineşti commune) on Somoş Hill and Vodoş Hill (Sacadău Stream), the town of Orașu Nou on Negru Hill, Ciap Hill, and Nucilor Hill, and along the Brada Mică and Ţiganul Valleys (see Figures 1 to 3). Slightly to the SW, 
outcrops are also noted near the village of Medieşul Aurit along the Trestios Stream. Outcrops exposing the rock are up to $500 \mathrm{~m}$ long and $30 \mathrm{~m}$ thick (Sagatovici et al. 1960; Stan \& Bîrlea 1967). One of the earliest mentions of this material in the literature was by Zepharovich (1859: 312-313). Since then various researchers have mentioned and described it (for examples, see Stan \& Bîrlea 1967; Edelstein et al. 1980; Borcoș \& Vlad 1994). A detailed study of the perlites of the Oaş Depression was made by Sagatovici et al. (1960) in which several outcrops of perlite between the villages of Coca and Orașu Nou (Figure 2) are described. The samples for this study came from Negru Hill, to the west of Orașu Nou (Figure 1).

Chalcedony from this area (in particular the blue chalcedony of Trestia) has been known since the $18^{\text {th }}$ century (Benkö 1786: 39). It forms veins of 1 to $15 \mathrm{~cm}$ thickness. Various researchers have written about it (Zepharovich 1859: 372; Zerrenner 1871; 1874; Manilici 1962; Moțiu \& Ghiurcă 1979; Ilinca 1989; Ghiurcă \& Chira 1998; Ionescu \& Ghergari 1999; 2000; Pop et al. 2004; Ilinca et al. 2009).

\section{Methods}

All of the materials in this study were analysed macroscopically, by eye, hand loupe and a Nikon SMZ645 stereomicroscope. Representative samples of each material were thin sectioned and analysed by polarized light optical microscopy using a Nikon Eclipse E200 Pol microscope. Images were captured with a Nikon D3100 DSLR camera. In total 22 samples, from 10 sources, were analysed microscopically. The macroscopic and microscopic observations of the samples were stored in a database using standardised terminology and descriptions by Crandell (2005; 2006). For a precise identification of the mineral composition, six samples ( 2 from Cremenea Hill, Racșa, 2 from Ilba, and 2 from Firiza) were analysed by X-ray powder diffraction (XRPD), using a Shimatzu 6000 diffractometer with CuKa radiation and $\mathrm{Ni}$ filter. The samples were measured from 5 to $80^{\circ} 2 \theta$, with a scan speed of $2 \% \mathrm{~min}$.

\section{Results and discussions}

\subsection{Jasper}

This jasper exhibits a wide range of colours, even within individual samples (Figure 4 ak). Typical colours include white to brown, red and orange and sometimes even black. They are fine to medium grained, and are often matt but sometimes have a glassy lustre. This material usually breaks with a conchoidal fracture that produces a sharp edge. Some of the samples from the Alba River near Negrești-Oaș (towards Boinești) contain gastropod shells (Figure 5). Samples at several locations contain fossilised plant remains that appear to have been reeds, for example, on Cremenea Hill (Racșa), in the Alba River (Negrești-Oaș), on Porcului Hill (Ilba).

Petrographic thin sections show that the material is composed primarily of quartz but with a high opal content and often Fe-oxihydroxides (Figure 6 a-h) and carbonate. Opal appears as isotropic mass with low refractive index. In some samples, there appears to be more opal than quartz (e.g., Figure 6 e \& f). Some samples have irregular bands of fibrous quartz (chalcedony). In some of the thin sections, the plant cell structure is very well preserved (Figure $6 \mathrm{c}$ ).

Based on macroscopic and microscopic characteristics, some of the samples, in particular ones from the Alba R. (Negrești-Oaș), Ilba, Iricau Peak (Baia Mare), Baia Sprie, and Cavnic, could also be categorised as 'opal' or 'limnic opal'. Indeed, XRPD analyses confirmed that in addition to quartz, many samples of this material also contain high quantities of opal-A and opal-CT (Crandell, in preparation). 

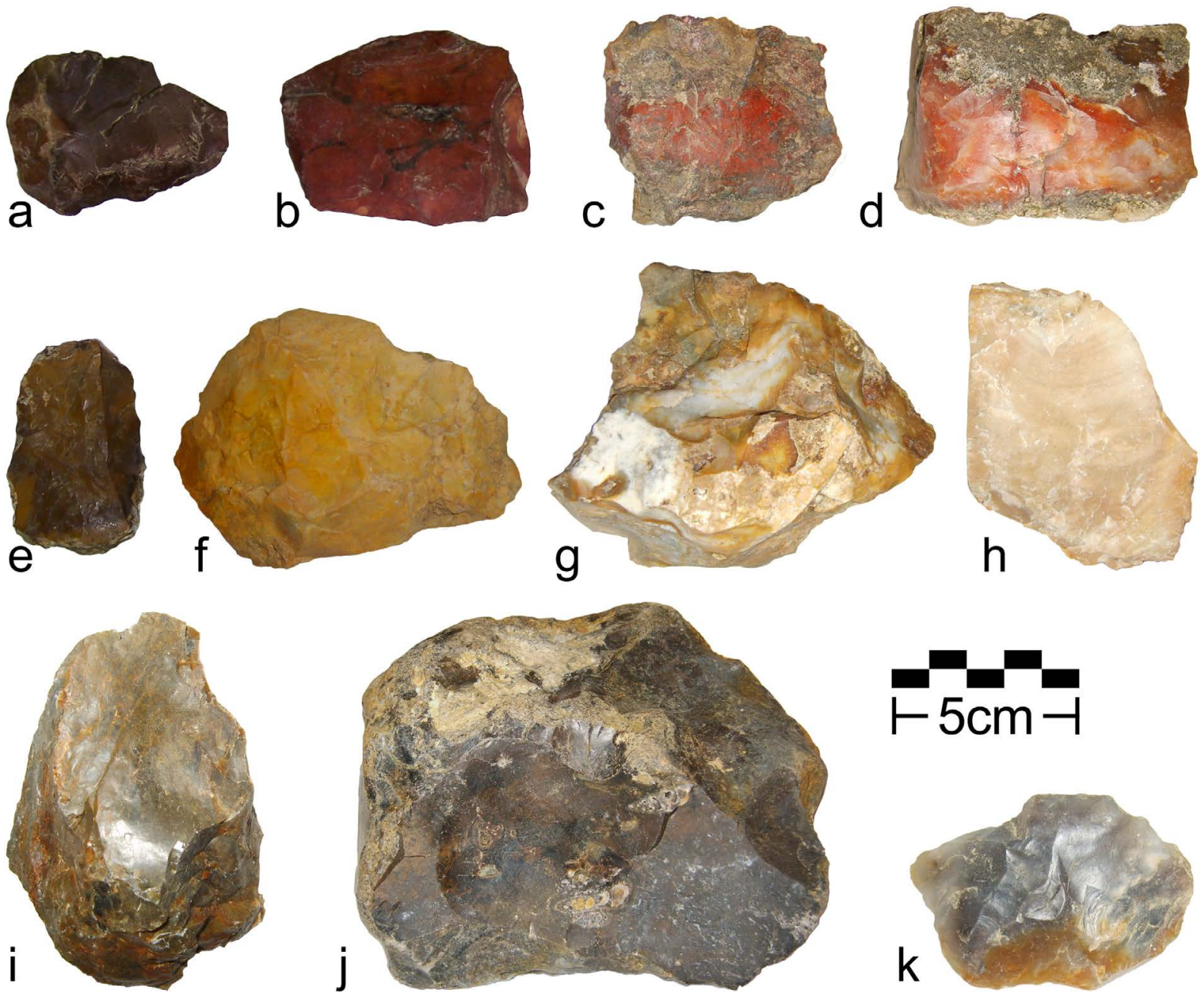

Figure 4. Sinter-opal samples from: a) Satului Valley (Racșa); b) Tancușului Valley (Racșa); c) Seini; d) Cremenea Hill (Racșa); e) Satului Valley (Racșa); f) \& g) Cremenea Hill (Racșa); h). Seini; i) Ilba; j) \& k. Alba R. (Negrești-Oaș). (All photos by the author. All samples from the author’s collection.)

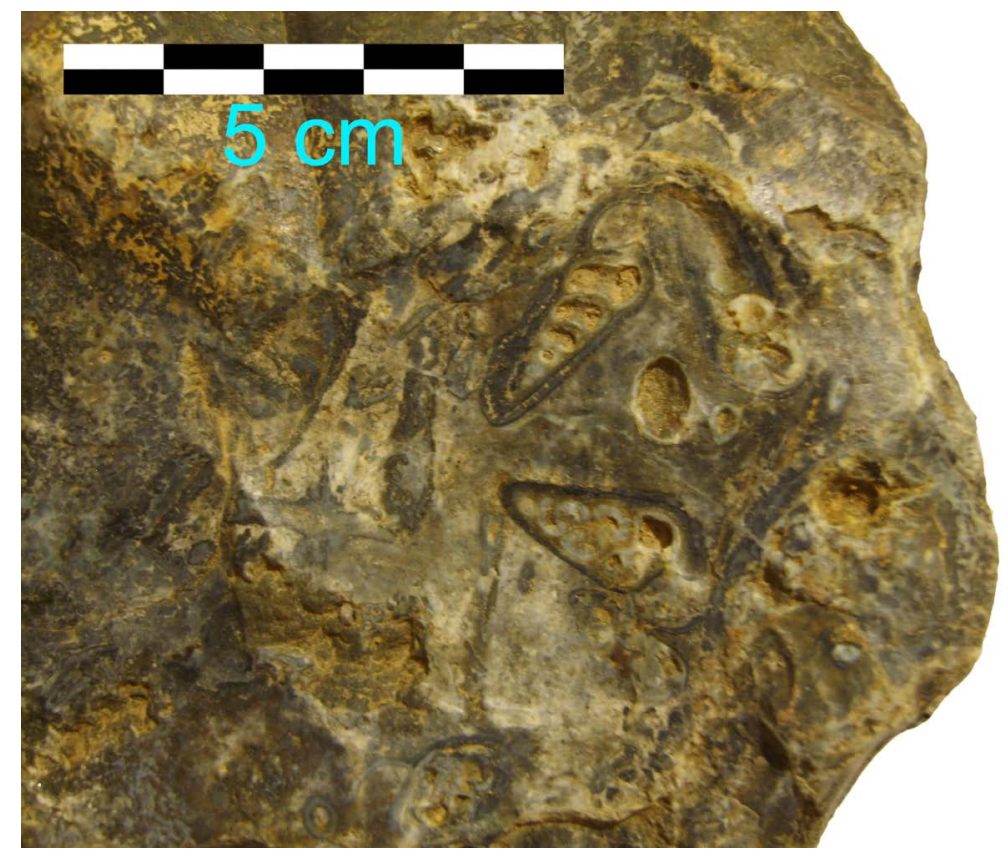

Figure 5. Material of limnic origin from the Alba River (Satu Mare County) showing macrofossil shells (gastropods). Same sample shown in Figure 4 j. (Photo by the author. Sample from the author's collection.) 

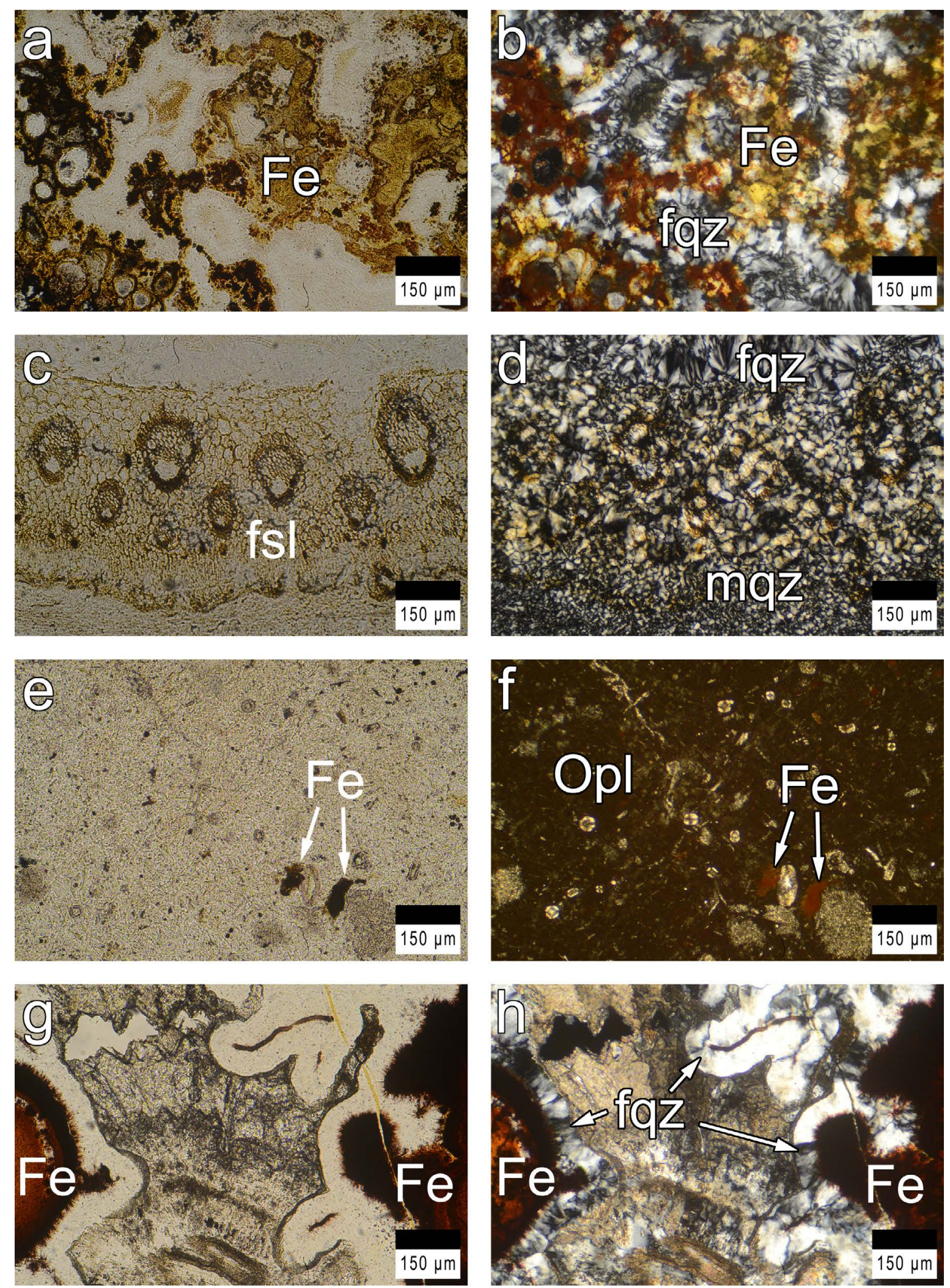

Figure 6. Polarised light microphotos of jasper samples. a) \& b) Seini; colomorph deposition of microquartz pigmented with Fe-oxihydroxides; small rounded opal concretions in the left side of the images; c) \& d) Cremenea Hill (Racșa); vegetal tissue remnants, totally replaced by a mixture of microquartz and opal; e) \& f) Ilba; isotropic mass of opal, with Fe- oxihydroxides and clusters of a material which seems to be carbonate; g) \& h) Firiza; colomorph and rhythmic depositions of Fe-rich microquartz, chalcedony (fibrous microquartz), and opal; This sample contains a high amount of carbonate mixed with fibrous microquartz. Left side, one polariser (1P). Right side, the same with crossed polarisers $(+P)$. Abbreviations: Fe for iron-rich phase, mqz for microgranular quartz, fqz for fibrous quartz, fsl for fossil plant tissue, Opl for opal. 
This material is well suited for knapping tools, but since it fractures a bit irregularly and is often more friable than the local materials of other areas, it is presumed that this material was not exported long distances and was instead used only locally. From observations of lithic assemblages at sites from the area, it appears that the main local material which was used for knapping tools was a sinter or sinter-opal.

\subsection{Perlite}

The material varies in colour but tends to be medium to dark grey (particularly dark greys), sometimes whitish grey, sometimes grey with brownish, greenish or reddish hue (sometimes occurring in bands). It often has a glassy lustre, with pearly appearance due to alteration. Most of the material has a typical 'perlitic fracture' or 'onion-skin tecture', i.e. it breaks up into small spherical globules or oval shaped pieces (Sagatovici et al. 1960; Stan \& Bîrlea 1967; Edelstein et al. 1980; Borcoș \& Vlad 1994). At some outcrops perlites show a conchoidal fracture. Macroscopically, the material is homogeneous and aphanitic, i.e. without visible components except for vacuoles. Zones with vacuoles often alternate with vacuole-free zones. Often fluidal texture due to the lava flow is visible.

Microscopically this material appears as a relatively homogenous glass, transparent (one polariser) and isotropic (crossed polarisers). Tiny crystallites and small K-feldspar and quartz crystals can be seen together with frequent gas bubbles (Figure 7 a \& b). These characteristics vary a lot and affect the quality of the material. In places, perlites are altered and transformed into a mixture of glass, clay minerals (montmorillonite, kaolinite), and zeolites.

The value of this material for knapping varies from outcrop to outcrop. Vacuoles and friability lower the usefulness of the material for knapping tools. In general, its suitability for making knapped tools seems to be low (and might not have been used at all).
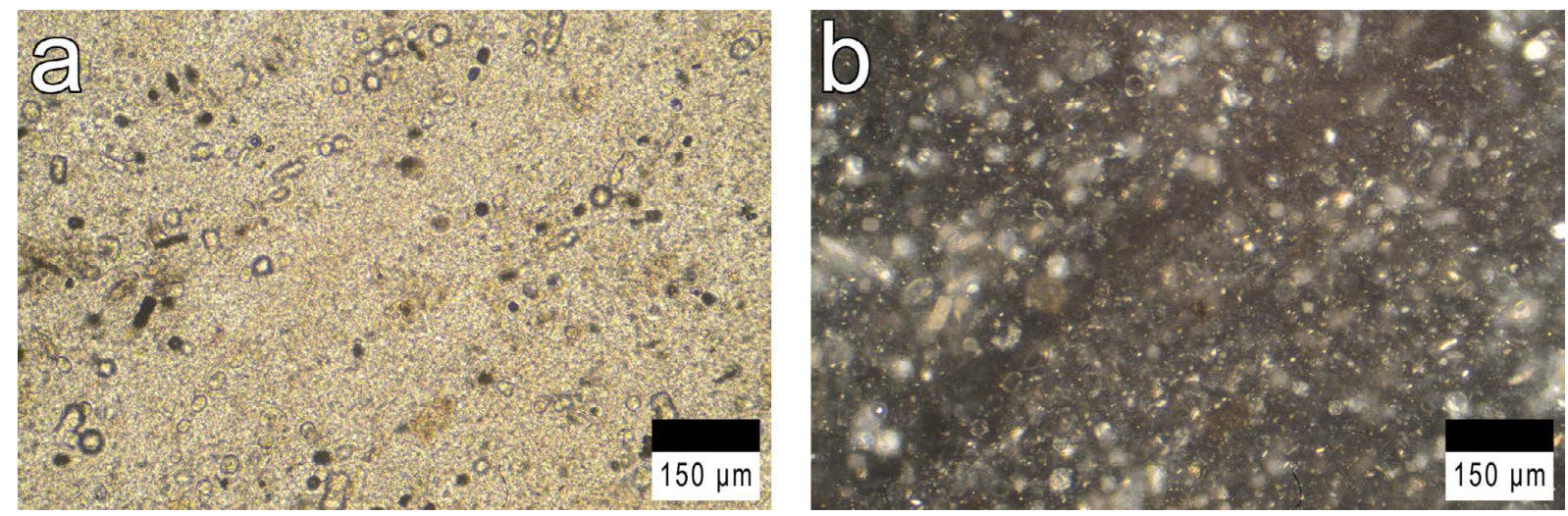

Figure 7. Microphotos of perlite from Orașu Nou. a) Transparent glassy material, with rounded gas bubbles and some Fe oxihydroxides (black spots in the image); b) Isotropic groundmass (dark) with crystallites and small feldspar and quartz crystals (light spots in the image). Left side, one polariser (1P). Right side, the same with crossed polarizers $(+\mathrm{P})$.

\subsection{Chalcedony}

Various massive or banded chalcedony (also called 'agate') sources associated with Neogene magmatics were found and sampled in the Oaș depression and in the Gutâi Mts. to its east, in particular at Vama, Racșa, Ilba, and Firiza. Colours vary but usually they are grey, white, brown, yellow, orange and blue (Figure $8 \mathrm{a}-\mathrm{c}$ ). Blue chalcedony, sometimes banded (Figure $8 \mathrm{~b}$ ), occurs in the area around Trestia, Plopiș, Surdești and Tisza Valley. (See Figures 1 and 2.) Microscopically it is composed almost purely of elongated microfibrous quartz, 
arranged either perpendicular to the wall or forming close packing rosettes (see Figure 9 a-d for examples).

According to archaeologists in the region, lithic artefacts with a blue colour are occasionally found. They are not common though. This may be due to the relatively small amount of chalcedony available in the area or because this material usually occurs in thin band. Some samples did not fracture with a very regular conchoidal fracture, and some contained macroquartz crystals, both of which lower its quality in terms of being knappable. Although the quality varies, some samples are suitable for knapping.

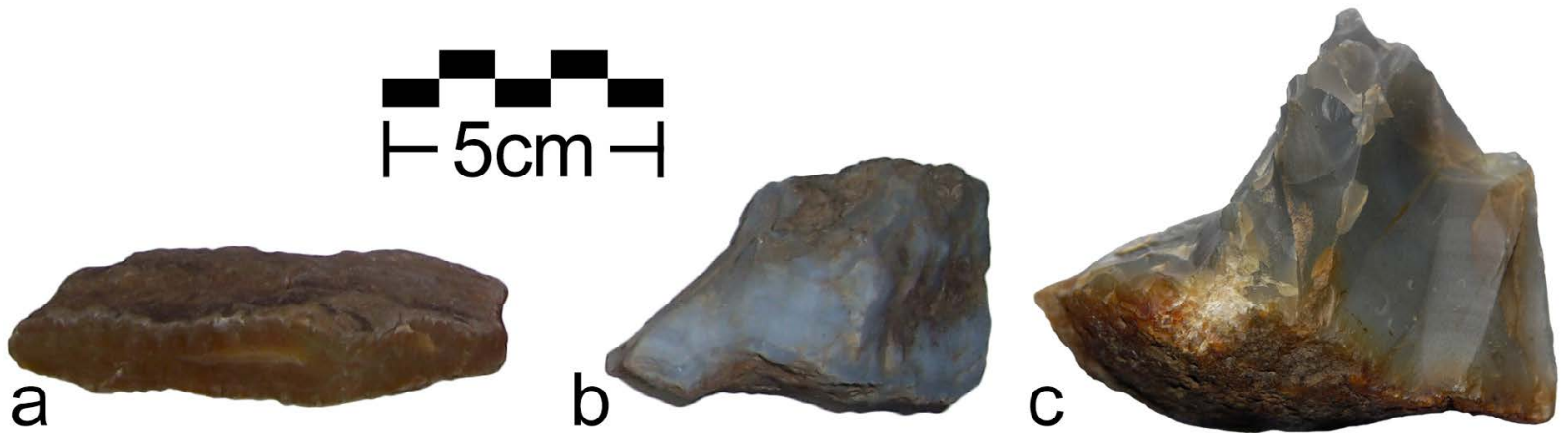

Figure 8. Samples of chalcedony from a) Răchișa Valley (near the village of Vama); b) \& c) Trestia. Samples a) and b) from the author's collection; sample c) from the Museum of Mineralogy, Babeș-Bolyai University.
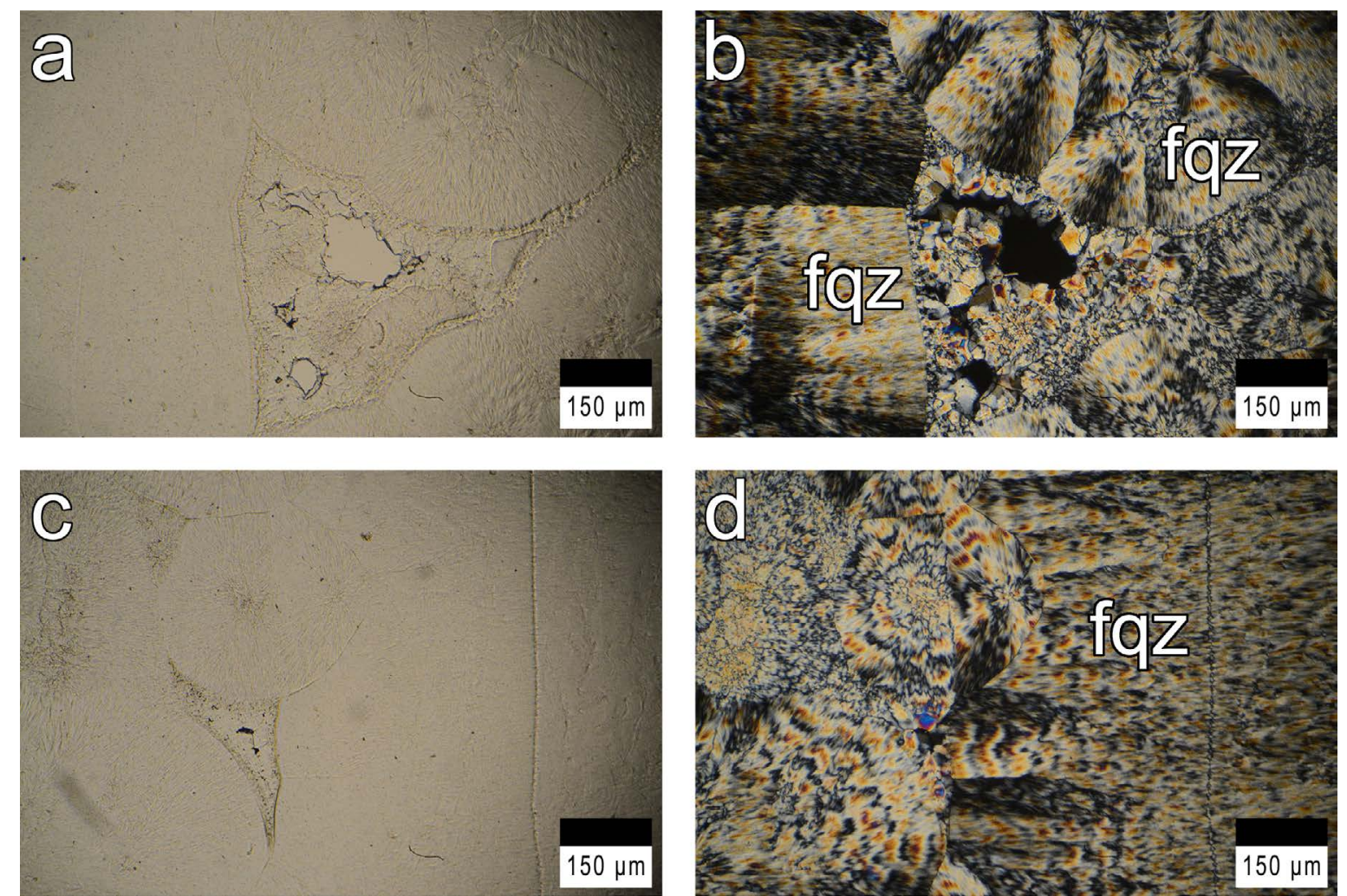

Figure 9. a), b), c), d). Microphotos (polarised light) of blue chalcedony from Trestia showing a transparent material composed of fibrous microquartz forming long and large fibres or packages of small rosettes. Left side, one polariser (1P). Right side, the same with crossed polarisers (+P). Abbreviations: fqz for fibrous quartz.

\subsection{Lithotheque}

The database of raw material sources is also available to researchers to compare artefacts and potential sources for provenance studies. Being able to source artefacts better will assist 
in determining trade routes and trade directions. In addition to recording the descriptions in of raw material sources and samples in a database, the representative physical samples collected in the field and the petrographic thin sections are included in the Romanian Lithotheque collection at Babeș-Bolyai University in Cluj-Napoca (Crandell 2009).

\section{Conclusions}

The combination of macroscopic features with microscopic features is important in any proper characterisation study of knappable materials. An objective description allows for sound interpretation in future archaeological research, in particular by assisting in identifying the sources of lithic artefacts. With the data presented here and the representative samples in the lithotheque, lithics researchers in NW Romania have reference materials which can be compared against similar characterisations of artefacts.

\section{Acknowledgements}

I would like to thank the following people who lent their assistance: Ciprian Astalos, for accompanying me on prospecting fieldwork and showing me some abundant outcrops in the area; Dr. Dana Lüttge-Pop, curator at the Museum of Mineralogy, Babeș-Bolyai University, for providing access to their rock collection and inventory volumes as well as help in identifying source locations of the museums rock samples; Dr. Ciprian Constantina, for noting some locations with outcrops. Although most of the samples analysed were collected during fieldwork, a few came from the Museum of Mineralogy of Babeș-Bolyai University. Financial support from the Romanian Ministry of Education and Research (PN-II-ID-PCE2011-3-0881 project) is also acknowledged.

\section{References}

Benkö, F. 1786, Magyar minerologia, az az a' kövek' 's értzek' tudománya. Nyomt. a' Réform. Kollégyom' Betüivel, Kolozsvár (Cluj-Napoca), 181 p. (in Hungarian) ("Hungarian mineralogy")

Borcoș, M. \& Vlad, Ș. 1994, Plate tectonics and metallogeny in the East Carpathians and Apuseni Mts. Field trip guide, 1994. Geological Institute of Romania, Bucharest, 43 p.

Crandell, O.N. 2005, Macroscopic analysis and characterisation of chert for provenance purposes. Sargetia, Acta Musei Devensis, 33: 137-153.

Crandell, O.N. 2006, Macroscopic and microscopic analysis of chert; A proposal for standardisation of methodology and terminology. Buletinul Cercurilor Științifice Studențești, 12: 7-30.

Crandell, O.N. 2009, Romanian Lithotheque Project: Knappable stone resources in the Mureș Valley, Romania. Studia Geologia, Special Issue, MAEGS - 16: 79-80.

URL: http://www.studia.ubbcluj.ro/arhiva/abstract_en.php?editie=GEOLOGIA\&nr=Sp ecial\%20Issue\&an=2009\&id_art=7388

Edelstein, O., Iștvan, D., Cojocea, C., Weisz, G., Bernad, A., Stan, D. \& Kovacs, M. 1980, Geological map of Oaș-Țibleș Mts.; 1:25000 scale. S.C. IPEG Maramureș S.A., Baia Mare. (in Romanian)

Ghiurcă, V. \& Chira, D. 1998, Resursele gemologice ale județului Maramureș. Studii și cercetări (Științele Naturii), 4: 5-13. (in Romanian) ("Gemological resources of Maramureș county") 
Givulescu, R. 1967, Cîteva precizări în legătură cu vîrsta depozitelor sedimentare din dealul Piciorul Porcului, comuna Ilba - reg. Maramureș. Comunicări de Geologie-Geografie, 4: 91-97. (in Romanian) ("Some details about age of the sedimentary deposits of Piciorul Porcului Hill, Ilba village - Maramureș region")

Ilinca, G. 1989, The chalcedony of Trestia-Maramureș. Dări de Seamă ale Ședințelor, 74(1): 21-34.

Ilinca, G., Ionescu, C. \& Ghergari, L. 2009, The "chalcedony" of Trestia, Maramureș (Romania) - Revisited. Studia Geologia UBB, Special Issue: 190-191.

URL: http://www.studia.ubbcluj.ro/arhiva/abstract_en.php?editie=GEOLOGIA\&nr=Sp ecial\%20Issue\&an=2009\&id_art=7467

Ionescu, C. \& Ghergari, L. 1999, Gems in the Quaternary deposits from Romania: blue quartz from Trestia-Maramures. In: INQUA XV International Congress abstracts; Durban, South Africa; August 3-11, 1999 (Partridge, T.C., Ed.), Durban: p. 87.

Ionescu, C. \& Ghergari, L. 2000, Gems in the Quaternary deposits from Romania: blue quartz from Trestia-Maramures. Quaternary International, 63-64: 63. doi:10.1016/s10406182(99)00031-2

Iorgulescu, T. 1955, Microfauna unor profile din sedimentarul zonei eruptive a regiunii Baia Mare. Dări de Seamă ale Ședințelor Comitetul Geologic, 39: 69-83. (in Romanian) ("Microfauna of sedimentary profiles of the eruptive zone of the Baia Mare region")

Manilici, V. 1962, Contribuțiuni la studiul rocilor efuzive din zona Baia Sprie - Dănești Trestia - Bloaja (regiunea Baia Mare). Dări de Seamă ale Comitetului Geologic al României, 46: 75-88. (in Romanian) ("Contributions to the study of effusive rocks from the Baia Sprie - Dănești - Trestia - Bloaja zone (Baia Mare region)")

Moțiu, A. \& Ghiurcă, V. 1979, Date noi privind calcedonia de Trestia. Studia Universitatis Babeș-Bolyai. Series geologia-geographia, 24(2): 24-31. (in Romanian) ("New data regarding the chalcedony of Trestia")

Pop, D., Constantina, C., Tătar, D. \& Kiefer, W. 2004, Raman spectroscopy on gem-quality microcrystalline and amorphous silica varieties from Romania. Studia UBB, Geologia, 49(1): 41-52. URL: http://scholarcommons.usf.edu/geologia/vol49/iss1/art4

Rădulescu, D. 1960, Studiul petrografic al formațiunilor eruptive Seini-Ilba-Nistru (Baia Mare). Anuarul Comitetului Geologic, 31: 151-294. (in Romanian) ("Petrographic study of the Seini-Ilba-Nistru (Baia Mare) eruptive formations")

Sagatovici, A., Arion, F. \& Popescu, I.C. 1960, Contribuțiuni la cunoașterea pertlitelor din Tara Oașului. Comunicări de Geologie-Geografie, 1: 45-50. (in Romanian)

("Contributions to the knowledge of the perlite rocks in Țara Oaşului")

Săndulescu, M., Kräutner, H., Borcoș, M., Năstăseanu, S., Patrulius, D., Ștefănescu, M., Ghenea, C., Lupu, M., Savu, H., Bercia, I. \& Marinescu, F. 1978, Geological map of Romania, 1:1,000,000 scale. Institute of Geology and Geophysics, Bucharest. (in Romanian)

SRTM 2000, Shuttle Radar Topography Mission (SRTM) Digital Elevation Models (DEMs). NGA (National Geospatial-Intelligence Agency) and NASA (National Aeronautics and Space Administration). Retrieved 15 March 2010.

URL: http://dds.cr.usgs.gov/srtm/version2_1/ 
Stan, N. \& Bîrlea, V. 1967, Puncte de vedere asupra vulcanismului neogen de la RacșaVama-Certeze. Dări de Seamă ale Ședințelor, Comitetul de Stat al Geologiei (19651966), 53(1): 215-234. (in Romanian) ("Views on the Neogene volcanism of RacșaVama-Certeze")

Tudor, G. 2009, GIR bedrock and superficial lithostratigraphy. Geological Survey of Romania. Retrieved 15 March 2013.

URL: http://37.128.225.60/ArcGIS_Server_IGR/services/GIR_Bedrock_and_Superficia l_Lithostratigraphy/MapServer/WMSServer?

Turq, A. 2005, Réflexions méthodologiques sur les études de matières premières lithiques. 1 des lithothèques au matériel archéologique. Paléo. Revue d'archéologie préhistorique, (17): 111-132. (in French) ("Methodological considerations about lithic studies. 1 - from lithotheques to archaeological samples") URL: http://paleo.revues.org/883

Zepharovich, V. 1859, Mineralogisches Lexicon für das Kaiserthum Österreich. Vol. 1. Wilhelm Braumüller, Vienna, 630 p. (in German) ("Mineralogical lexicon of the Austrian Empire")

Zerrenner, C. 1871, Der Chalcedon von Trestyan. Neues Jahrbuch für Mineralogie, Geologie und Paläontologie: 81-82. (in German) ("The chalcedony of Trestia")

Zerrenner, C. 1874, Chalcedon von Trestyan. Mineralogische Mittheilungen: 94. (in German) ("Chalcedony of Trestia") 